\title{
Perilaku Pencegahan Penularan dan Faktor-Faktor yang Melatarbelakanginya pada Pasien Tuberculosis Multidrugs Resistance (TB $M D R)$
}

\author{
Iis Nurhayati ${ }^{1}$, Titis Kurniawan ${ }^{2}$, Wiwi Mardiah ${ }^{2}$ \\ ${ }^{1} \mathrm{RSHS},{ }^{2}$ Fakultas Keperawatan, Universitas Padjadjaran \\ E-Mailiis.nurhayati1978@gmail.comataut.kurniawan.1981@gmail.com
}

\begin{abstract}
Abstrak
Tuberculosis Multidrugs Resistance (TB-MDR) merupakan masalah serius di Indonesia. Selain memiliki risiko penularan yang tinggi, TB-MDR mempunyai banyak hambatan dalam pengobatan, baik lama pengobatan, jumlah obat yang banyak, dan efek samping yang buruk. DHal ini menjadi penting mengidentifikasi perilaku pencegahan penularan pada pasien TB-MDR beserta faktor yang melatarbelakanginya. Penelitian ini bertujuan untuk mengidentifikasi perilaku penderita TB-MDR dalam mencegah penularan beserta faktor yang melatarbelakanginya. Penelitian deskriptif korelasional ini melibatkan seluruh pasien TB-MDR yang sedang menjalani pengobatan fase intensif hingga November 2014 di Rumah Sakit Hasan Sadikin sebanyak 61 orang. Data karakteristik responden, perilaku dan faktor-faktor yang melatarbelakanginya dikumpulkan menggunakan kuesioner. Data yang terkumpul dianalisis secara deskriptif dan dihubungkan satu sama lain (independent t-test, one way annova, dan Pearson Correlational test). Hasil penelitian menunjukkan bahwa lebih dari setengah responden berpendidikan SMA $(54,1 \%)$, berjenis kelamin laki-laki $(60,6 \%)$, tipe MDR gagal pengobatan kategori $1 \& 2(60,7 \%)$, berusia $<44$ tahun $(68,9 \%)$, sebagian besar menikah $(75,4 \%)$ dan berpenghasilan di bawah UMR $(81,9 \%)$, serta mengeluhkan efek samping berupa mual $(90,1 \%)$. Lebih dari setengah responden $(57,4 \%)$ melaporkan perilaku pencegahan penularan yang baik. Perilaku pencegahan penularan ditemukan berhubungan secara bermakna dengan jenis kelamin $(\mathrm{p}=$ $0,01)$, perceived benefit $(p=0,02)$, cues to action $(p=0,00)$, dan self efficacy $(p=0,006)$. Akan tetapi, tidak ditemukan adanya hubungan yang bermakna antara perilaku pencegahan dengan data demografi (usia, satatus pernikahan, tingkat pendidikan, dan penghasilan) maupun tipe MDR ( $p>0,05)$. Hal ini menjadi penting bagi tenaga kesehatan untuk memperkuat faktor tersebut sebagai upaya meningkatkan perilaku pencegahan transmisi/penularan TB.
\end{abstract}

Kata kunci: Faktor, pencegahan penularan, TB-MDR.

\section{Prevention Behaviors and Its' Contributing Factors among Patients with Multi-drugs Resistance Tuberculosis (MDR-TB)}

\begin{abstract}
Multi-drugs Resistance Tuberculosis (MDR-TB) is a serious health problem in Indonesia. Beside the risk of transmission, the treatment of MDR-TB encounters some obstacles namely lengthy medication, multiple drugs and adverse side effects. Therefore, it is important to identify patients' prevention behaviors and its contributing factors. This study was aimed to identify MDR-TB patients' prevention behaviors and its' contributing factors. This descriptive correlational study involved all (61 patients) of MDR-TB patients who received intensive medication until November 2014 in Dr. Hasan Sadikin Hospital. Demographic and health characteristics data, as well as behaviors and its related factors were collected using questionnaires. Data were analyzed using descriptive analyses and correlational test (independent t-test, one way ANOVA, and Pearson correlation test). The results showed that more than half of respondents were male (60.6\%), MDR with failed medication type $1 \& 2(60.7 \%)$, age less than 44 years old $(68.9 \%)$, mostly married $(75.4 \%)$, had income less than minimum standard $(81.9 \%)$, and experienced nausea as the medication's side effect $(90.1 \%)$. Additionally, more than half of respondents $(57.4 \%)$ reported good prevention behaviors. These behaviors significantly related to female gender $(p=0.01)$, perceived benefit $(p=0.02)$, cues to action $(p=0.000)$, and self-efficacy $(p=0.006)$. However, there was not any significant relationship between the prevention behaviors and demographic data (age, educational level, marital status, and income) or between the behaviors and patients' medication categories ( $\mathrm{p}>0.05)$. Generally, MDR-TB patients in this study performed good preventive behaviors and it was related to their perceived benefit, cues to action, and self-efficacy. Therefore, it is important for healthcare professional to empower these identified factors in order to minimize the MDR-TB transmission.
\end{abstract}

Key words: Factors, MDR-TB, prevention behaviors. 
Iis Nurhayati: Perilaku Pencegahan Penularan dan Faktor-Faktor yang Melatarbelakanginya

\section{Pendahuluan}

Tuberkulosis (TB) merupakan penyakit infeksi salah satu penyebab terbesar kematian di dunia (Smeltzer, Bare, Hinkle \& Cheever, 2010). WHO melaporkan, pada tahun 2012 sebanyak 8,6 juta orang terkena TB kasus baru dan 1,3 juta orang diantaranya meninggal. Indonesia merupakan negara dengan pasien TB terbanyak ke-5 di dunia dan berada di urutan 8 dari 27 negara dengan beban TB-MDR terbanyak di dunia (WHO, 2013). Kementerian Kesehatan RI (2014) melaporkan ada sekitar 6.900 pasien TB MDR dengan 5.900 orang $(1,9 \%)$ kasus baru dan 1.000 orang $(12 \%)$ dari kasus pengobatan ulang. Jumlah penemuan suspek TB-MDR di Jawa Barat hingga Oktober 2014 sebanyak 764 orang, telah terkonfirmasi menderita TB MDR sebanyak 303 orang, dan dalam masa pengobatan sebanyak 203 orang, sebanyak 64 orang pada fase intensif dan 139 orang fase lanjutan dengan jumlah penderita terbanyak di Bandung yaitu 30 orang (Register TB MDR RSUP DR. Hasan Sadikin Bandung, 2014).

TB-MDR merupakan suatu jenis resistensi bakteri TB terhadap minimal dua obat anti TB lini pertama, yaitu Isoniazid dan Rifampicin yang merupakan dua obat TB yang paling efektif. TB-MDR menjadi tantangan baru dalam program pengendalian $\mathrm{TB}$ karena penegakan diagnosis yang sulit, tingginya angka kegagalan terapi dan kematian (Kementerian Kesehatan RI, 2011). Salah satu faktor kegagalan pengobatan pengobatan TB MDR adalah kepatuhan pasien dalam pengobatan. Padahal, salah satu faktor resiko yang paling berpengaruh terhadap kejadian TB MDR adalah riwayat ketidakpatuhan pada pengobatan sebelumnya (Andriyanti, 2013). Sayangnya ketidakpatuhan dalam menjalankan pengobatan TB masih banyak ditemukan. Bagiada(2010) melaporkan diBali menunjukkan jumlah TB paru yang mangkir sebanyak $12,9 \%$, dan $45 \%$ diantaranya tidak ditemukan dalam pelacakan.

Sejak tahun 2009 pemerintah Republik Indonesia telah menerapkan strategi pengelolaan pasien TB MDR menggunakan Programatic Management Drug Resistance Tuberculosis (PMDT). Meski program telah dijalankan, penanganan TB MDR belum mencapai target yang diharapkan. Penelitian Bertin (2011) di Jawa Tengah, menemukan $60 \%$ penderita TB MDR gagal dalam pengobatan. Sifat bakteri yang telah resisten menyebabkan pasien harus menjalani pengobatan dengan durasi yang lebih lama, jumlah obat yang lebih banyak, efek samping pengobatan yang jauh lebih buruk, dan akhirnya tingkat kesembuhan relatif rendah. Di Jawa Barat, program ini baru dijalankan di RSHS Bandung pada tahun 2012 (Kementerian Kesehatan RI, 2014).

Selain angka kesembuhan yang rendah, TB MDR berisiko menularkan langsung kuman yang telah resisten sehingga berisiko memunculkan resistensi primer pada orang yang tertular. Dengan kata lain, seseorang yang belum pernah terkena TB sebelumnya bisa langsung menjadi TB MDR ketika tertular TB MDR. Penelitian Sihombing, Sembiring, Amir, dan Sinaga (2012) di Medan menemukan $41,18 \%$ kejadian resistensi terhadap obat TB lini pertama, dan 4,71\% diantaranya adalah TB MDR primer.

Pasien juga melaporkan beberapa hambatan terkait pengobatan TB MDR. Munawwarah (2013) menemukan bahwa $60 \%$ penderita TB MDR sudah pernah mendapatkan pengobatan TB sebelumnya lebih dari sekali, $60 \%$ penderita mengalami kejenuhan akibat lamanya pengobatan, menyatakan kesulitan dalam biaya selama pengobatan, dan seluruh penderita melaporkan efek samping pengobatan seperti mual, nyeri sendi, pusing, gangguan penglihatan, gangguan pendengaran, dan rasa panas di dada.

Beberapa penelitian mengindikasikan perilaku pencegahan penularan TB masih rendah. Hal ini dapat menimbulkan masalah baru yaitu munculnya kuman TB yang resisten terhadap obat anti tuberculosis. Helper dan Sahat (2010) menemukan bahwa penderita TB paru mempunyai kebiasaan sering tidak menutup mulut saat batuk.

Terkait perilaku pencegahan pada pasien TB, penelitian Jahan (2014) di Dhaka menemukan bahwa pasien TB memiliki perilaku pencegahan tingkat menengah, dan perilaku tersebut diketahui berhubungan dengan pengetahuan, perceive benefit, susceptibility, severity, dan perceive barrier. Hal ini berbeda dengan hasil penelitian di 
Iis Nurhayati: Perilaku Pencegahan Penularan dan Faktor-Faktor yang Melatarbelakanginya

Kenya yang menemukan bahwa perilaku pencegahan TB relatif baik dan diketahui berhubungan erat dengan pengetahuan, sikap, dan agama (Yusuf, 2008).

Penelitian terkait perilaku pencegahan juga dilakukan pada responden yang bukan pasien TB. Penelitian pada pasien rawat jalan (non-TB) di rumah sakit KanchanaburiThailand menemukan bahwa mereka memiliki perilaku pencegahan yang baik, dan perilaku tersebut berhubungan erat dengan pengetahuan TB, pendidikan, pekerjaan, dan akses terhadap informasi (Sokhanya, Sermsri, \& Chompikul, 2008). Penelitian lainnya pada imigran Myanmar menemukan tingkat perilaku pencegahan TB yang belum baik dan perilaku tersebut ditemukan berhubungan dengan pengetahuan namun tidak berhubungan dengan persepsi terkait TB (Thwin, 2008)

Ditinjau dari teori Health belief model (HBM) dari Becker \& Rosenstosk (1984) dalam Glanz et al, (2008), perilaku kesehatan individu dipengaruhi persepsi/keyakinan kerentanan terhadap suatu penyakit (Perceived susceptibility), persepsi terhadap konsekuensi/ keseriusan akibat penyakit (Perceived Severity), keuntungan yang didapat untuk melakukan perilaku kesehatan yang disarankan (Perceived benefits), besar hambatan yang ditemui (Perceived barriers), kesiapan menjalankan (Cues to action) dan kepercayaan diri untuk melakukan tindakan (Self-efficacy). Dengan kata lain, perilaku penderita TB MDR dalam melakukan pencegahan penularan dipengaruhi oleh persepsi/keyakinan penderita mengenai kerentanan mereka terhadap penyakit TB, persepsi tentang seberapa serius kondisi dan konsekuensi yang ditimbulkan oleh $\mathrm{TB}$, keuntungan dan besarnya hambatan yang ditemui untuk melakukan pencegahan penularan serta kepercayaan diri untuk melakukan pencegahan penularan TB (Glanz et al, 2008).

Penelitian-penelitian sebelumnya terkait perilaku pencegahan dan faktor yang berhubungan dengan perilaku pencegahan dilakukan pada kelompok responden non TB MDR dan non TB. Hal ini menjadi penting mengidentifikasi variabel tersebut pada pasien TB MDR. Selain sebagai sumber penularan yang diharapkan mampu menjalankan penceghaan dengan baik, pasien TB MDR memiliki keuikan karakteristik dibanding responden lainnya, baik terkait riwayat kegagalan pengobatan TB sebelumnya, panjangnya durasi pengobatan dan banyaknya jumlah obat yang harus diminum.

\section{Metode Penelitian}

Penelitian deskriptif kuantitatif ini dilakukan secara cross-sectional. Variabel pada penelitian ini adalah perilaku pencegahan penularan TB-MDR yang mencakup: pengobatan, manajemen kontak, pengelolaan dahak, etika batuk, penggunaan masker, hand hygiene, pengelolaan peralatan makan, dan pengelolaan kesehatan lingkungan rumah. Adapun variabel faktor-faktor yang berhubungan dengan perilaku penderita TB MDR dalam mencegah penularan, mencakup: perceived susceptibility, perceived severity, perceived barriers, perceived benefits, cues to action, self-efficacy.

Penelitian ini melibatkan seluruh penderita TB MDR di Jawa Barat yang sedang menjalani pengobatan fase intensif di Rumah Sakit Hasan Sadikin Bandung pada Bulan November 2014 sebanyak 64 orang. Data dalam penelitian ini dikumpulkan menggunakan beberapa angket/kuesioner. Kuesioner tentang perilaku terdiri dari 8 komponen dan 23 item pernyataan dengan 4 opsi jawaban: selalu, sering, kadang-kadang, dan tidak pernah. Adapun kuesioner faktorfaktor yang berhubungan perilaku terdiri dari 43 item dengan 4 opsi jawaban: sangat setuju, setuju, tidak setuju, dan sangat tidak setuju. Selain dilakukan uji face validity, kedua instrumen telah diuji pada 30 responden, dimana untuk kuesioner perilaku didapatkan hasil Chronbach Alpa 0,731 dan untuk faktor-faktor berdasarkan komponen HBM memiliki Chronbach Alpa 0,860.

Data yang terkumpul kemudian dianalisis secara deskriptif dan dikategorikan berdasarkan nilai mean dari total skor seluruh responden. Untuk perilaku, jika total skor responden $>$ nilai mean skor seluruh responden $(78,85)$, maka responden tersebut dikategorikan berperilaku baik, dan sebaliknya. Komponen HBM, jika total skor responden $>$ nilai mean dari total skor 
Iis Nurhayati: Perilaku Pencegahan Penularan dan Faktor-Faktor yang Melatarbelakanginya

seluruh responden pada tiap komponen HBM (severity (17,79), benefit $(29,67)$, barrier $(21,18)$, cues to action $(22,8)$, dan self efficacy $(36,23))$, maka responden tersebut dikategorikan menjadi persepsi positif dan sebaliknya. Data-data tersebut kemudian dihubungkan satu sama lain guna menemukan faktor (HBM) yang berhubungan dengan perilaku pencegahan penularan TB MDR dengan signifikansi $\mathrm{p}<0,05$. Untuk melihat perbedaan antarkelompok kategori karakteristik dilakukan analisis menggunakan independent t-test dan one way anova. Adapun perilaku dan faktor dalam HBM dianalisis menggunakan Pearson correlational test.

\section{Hasil Penelitian}

Selama pengumpulan data, ada 2 pasien yang tidak datang (mangkir) dan 1 orang diketahui meninggal. Data didapatkan bahwa dari total 64 pasien TB MDR, hanya 61 orang yang bisa dikumpulkan datanya secara lengkap.

Secara umum pada tabel 1 dijelaskan sebagian besar responden berjenis kelamin laki-laki $(60,6 \%)$, berusia kurang dari 44 tahun $(68,9 \%)$, menikah $(75,4 \%)$, dan berpenghasilan di bawah UMR Kota Bandung (81,9\%). Berdasarkan pendidikan, responden terbesar berda pada kelompok pendidikan SMA $(54,1 \%)$. Berdasarkan tabel 2 nampak bahwa gagal pengobatan kategori 2 merupakan kategori pasien terbanyak $(39,4 \%)$ dan mual merupakan sebagai keluhan yang paling banyak dikeluhkan (90,1\%).

Tabel 3 diketahui bahwa secara umum lebih banyak responden yang sudah melakukan pencegahan penularan dengan baik $(57,4 \%)$. Di lihat berdasarkan komponen penceghan penularan TB, etika batuk merupakan komponen pencegahan penularan dimana persentase responden dengan kategori baik paling banyak $(80,3 \%)$ dan penggunaan masker merupakan komponen pencegahan yang paling sedikit dilakukan dengan baik $925 \%$ ). Tabel 4, nampak bahwa dari 5 komponen HBM, self efficacy merupakan komponen dengan persentase responden berpersepsi negatif paling banyak $(65,6 \%)$.

Tabel 1 Distribusi Frekuensi dan Persentase Karakteristik Responden (n=61)

\begin{tabular}{lcc}
\hline \multicolumn{1}{c}{ Karakteristik } & f & (\%) \\
\hline Usia & 42 & 68,9 \\
$<44$ tahun & 19 & 31,1 \\
$>45-54$ Tahun & & \\
Status Perkawinan & 46 & 75,4 \\
Menikah & 15 & 24,6 \\
Belum Menikah/duda/janda & & \\
Jenis Kelamin & 37 & 60,6 \\
Laki- Laki & 24 & 39,4 \\
Perempuan & & \\
Status Pekerjaan & 39 & 63,9 \\
Bekerja & 22 & 36,1 \\
Tidak bekerja & & \\
Status Pendidikan & 6 & 9,9 \\
SD & 13 & 21,3 \\
SMP & 33 & 54,1 \\
SMA & 9 & 14,7 \\
Perguruan Tinggi & & \\
Pendapatan Keluarga & 50 & 81,9 \\
$\leq$ UMR & 11 & 18,1 \\
$>$ UMR & & \\
\hline & &
\end{tabular}


Iis Nurhayati: Perilaku Pencegahan Penularan dan Faktor-Faktor yang Melatarbelakanginya

Tabel 2 Distribusi Frekuensi dan Persentase Data Kesehatan Responden $(\mathbf{n}=61)$

\begin{tabular}{lcc}
\hline \multicolumn{1}{c}{ Variabel } & f & $(\mathbf{\% )}$ \\
\hline \multicolumn{1}{c}{ Tipe pasien } & & \\
\hline Default (tidak tuntas) & 9 & 14,7 \\
Relaps (kambuh) & 15 & 24,6 \\
Gagal pengobatan Kategori 1 & 13 & 21,3 \\
Gagal pengobatan Kategori 2 & 24 & 39,4 \\
Efek Samping Pengobatan & & \\
Nyeri sendi & 46 & 75,4 \\
Pusing & 51 & 83,6 \\
Mual & 58 & 90,1 \\
\hline
\end{tabular}

Tabel 3 Distribusi Frekuensi Perilaku Pencegahan Penularan TB MDR pada Pasien TB MDR di RSUP Dr. Hasan Sadikin Bandung $(\mathrm{n}=61)$

\begin{tabular}{lcccc}
\hline \multicolumn{1}{c}{ Perilaku pencegahan penularan TB MDR } & \multicolumn{2}{c}{ Baik } & \multicolumn{2}{c}{ Buruk } \\
\hline Perilaku Pencegahan (Mean+SD $=78,85+7,023)$ & f & \% & f & \% \\
Komponen pengobatan & 35 & 57,4 & 26 & 42,6 \\
Komponen kontak serumah & 45 & 73,8 & 16 & 26,2 \\
Komponen pengelolaan dahak dan ludah & 30 & 49,2 & 31 & 50,8 \\
Komponen penggunaan masker & 34 & 55,7 & 27 & 44,3 \\
Komponen etika batuk & 25 & 41,0 & 36 & 59,0 \\
Komponen pemeliharaan kebersihan tangan & 49 & 80,3 & 12 & 19,7 \\
Komponen pengelolaan peralatan makan & 41 & 67,2 & 20 & 32,8 \\
Komponen pengelolaan kesehatan rumah & 34 & 55,7 & 27 & 44,3 \\
\hline
\end{tabular}

Tabel 4 Distribusi Frekuensi dan Persentase Faktor yang Berkontribusi terhadap Perilaku Pencegahan Penularan TB MDR berdasar Health Belief Model [HBM] (n=61)

\begin{tabular}{lcccc}
\hline \multicolumn{1}{c}{$\begin{array}{c}\text { Faktor yang melatarbelakangi berdasar HBM } \\
\text { (Mean+SD) }\end{array}$} & f & Positif & f & Negatif \\
\cline { 2 - 5 } & 35 & 57,4 & 26 & 42,6 \\
\hline Perceived susceptibility \& severity $(17,79+2,23)$ & 28 & 45,9 & 33 & 54,1 \\
Perceived barrier $(21,18+2,76)$ & 31 & 50,8 & 30 & 49,2 \\
Perceived benefits $(29,67+3,16)$ & 35 & 57,4 & 26 & 42,6 \\
Cues to action $(22,84+2,42)$ & 21 & 34,4 & 40 & 65,6 \\
Self efficacy (36,23+4,53) & & & & \\
\hline
\end{tabular}

Disimpulkan, lebih dari setengah responden merasa tidak yakin mampu menjalankan pencegahan penularan TB MDR.

Tabel 5 dapat diketahui bahwa perilaku pencegahan yang baik (mean lebih besar) ditemukan pada kelompok responden yang berjenis kelamin wanita $(81,5+$ $5,23)$, berpendidikan SMP $(81,69+4,85)$, berpenghasilan lebih tinggi dari UMR (81
$+7,23)$, dan pasien dengan kategori default $(81,11+5,71)$. Meski demikian, analisis lebih lanjut hanya menemukan adanya perbedaan yang bermakna perilaku pencegahan penularan TB MDR antara jenis pasien TB MDR pria dan wanita $(\mathrm{p}<0,05)$.

Tabel 6, terlihat bahwa perilaku pencegahan penularan pada pasien TB MDR berhubungan secara bermakna dengan perceived benefit ( $\mathrm{p}$ 
Iis Nurhayati: Perilaku Pencegahan Penularan dan Faktor-Faktor yang Melatarbelakanginya

Tabel 5 Hubungan Perilaku dan Karakteristik Responden $(\mathrm{n}=61)$

\begin{tabular}{|c|c|c|c|}
\hline \multirow[t]{2}{*}{ Karakteristik } & & Perilaku & $p$ \\
\hline & \multicolumn{3}{|c|}{ Mean (SD) } \\
\hline \multirow[t]{2}{*}{ Usia } & $<44$ tahun & $78,86(7,27)$ & $0,99^{\mathrm{a}}$ \\
\hline & $>$ 45-54 Tahun & $78,84(6,64)$ & \\
\hline \multirow{2}{*}{$\begin{array}{l}\text { Jenis } \\
\text { Kelamin }\end{array}$} & Pria & $77,14(7,53)$ & $0,01^{\mathrm{a}}$ \\
\hline & Wanita & $81,5(5,23)$ & \\
\hline \multirow[t]{4}{*}{ Pendidikan } & SD & $80,67(5,61)$ & $0,13^{b}$ \\
\hline & SMP & $81,69(4,85)$ & \\
\hline & SMA & $76,94(7,66)$ & \\
\hline & Perguruan Tinggi & $80,56(6,82)$ & \\
\hline \multirow[t]{2}{*}{ Status Perkawinan } & Belum Menikah/duda/janda & $78,6(6,92)$ & $0,87^{\mathrm{a}}$ \\
\hline & Menikah & $78,9(7,13)$ & \\
\hline Penghasilan & $<\mathrm{UMR}$ & $78,38(6,96)$ & $0,29^{\mathrm{a}}$ \\
\hline Bekerja & > UMR & $81,0(7,23)$ & \\
\hline \multirow[t]{4}{*}{ Kategori pasien } & Relaps & $79.08(8,35)$ & $0,74^{\mathrm{b}}$ \\
\hline & Default & $81,11(5,71)$ & \\
\hline & Gagal Kategori 1 & $77,93(7,01)$ & \\
\hline & Gagal Kategori 2 & $78,46(6,95)$ & \\
\hline
\end{tabular}

$a=$ independent t-test; $b=$ one way anova

Tabel 6 Hubungan Perilaku Pencegahan pada Pasien TB MDR dan Faktor-Faktor menurut HBM yang Berkontribusi terhadap Perilaku Tersebut $(n=61)$

\begin{tabular}{|c|c|c|c|c|c|c|}
\hline & $\begin{array}{c}\text { Perilaku } \\
\text { pencegahan }\end{array}$ & $\begin{array}{c}\text { Perceived } \\
\text { Susceptibilitiy } \\
\text { \& severity }\end{array}$ & $\begin{array}{l}\text { Perceived } \\
\text { barrier }\end{array}$ & $\begin{array}{c}\text { Perceived } \\
\text { benefit }\end{array}$ & $\begin{array}{c}\text { Cues to } \\
\text { action }\end{array}$ & $\begin{array}{c}\text { Self } \\
\text { Efficacy }\end{array}$ \\
\hline Perilaku Pencegahan & - & 0,09 & 0,03 & $0,31 *$ & $0,58 * *$ & $0,35^{*}$ \\
\hline $\begin{array}{l}\text { Perceived Susceptibilitiy \& } \\
\text { Severity }\end{array}$ & & - & $-0,21$ & 0,19 & 0,11 & 0,092 \\
\hline Perceived barrier & & & - &,$- 032 *$ & $-0,01$ & 0,04 \\
\hline Perceived benefit & & & & - & $0,56^{* *}$ & $0,35 * *$ \\
\hline Cues to action & & & & & - & $0.63 * *$ \\
\hline Self efficacy & & & & & & - \\
\hline
\end{tabular}


Iis Nurhayati: Perilaku Pencegahan Penularan dan Faktor-Faktor yang Melatarbelakanginya

$<0,05)$, cues to action $(\mathrm{p}<0,01)$, dan self efficacy $(\mathrm{p}<0,05)$. Ditemukan juga adanya hubungan yang bermakna antara perceived benefit dengan cues to action dan self efficacy serta hubungan yang bermakna antara cues to action dan self efficacy.

\section{Pembahasan}

Hasil penelitian menunjukkan bahwa secara umum lebih dari setengah responden $(57,4 \%)$ melaporkan perilaku pencegahan penularan pada pasien TB MDR yang baik. Hal ini menunjukkan bahwa secara kumulatif pasien TB MDR yang menjalani pengobatan di RSHS Bandung sudah menjalankan pencegahan dengan baik. Temuan ini salah satunya disebabkan karena dilihat karakteristik kategori pasien, semua responden dalam penelitian ini memiliki riwayat TB sebelumnya dan tidak menjalani pengobatan secara tuntas (relaps maupun gagal pengobatan golongan $1 \& 2$ ). Dengan riwayat pernah menjalani pengobatan sebelumnya, memungkinkan pasien memiliki pemahaman yang baik terkait cara pencegahan TB, manfaat dan dampak bila tidak melakukan pencegahan. Pada penelitian lain ditemukan bahwa akses informasi dan pengetahuan tentang TB berhubungan erat dengan perilaku pencegahan TB (Sokhanya, Sermsri, \& Chompikul, 2008; Yusuf, 2014).

Temuan serupa juga dijumpai pada penelitian dengan populasi non TB. Penelitian pada pasien rawat jalan di rumah sakit di Thailand menemukan perilaku pencegahan yang baik (Sokhanya, Sermsri \& Chompikul, 2008) dibandingkan. Sebaliknya, penelitian pada kelompok pengungsi di Myanmar menemukan perilaku pencegahan TB yang buruk (Thwin, 2008). Keduanya menyatakan bahwa perilaku tersebut berhubungan dengan pengetahuan responden. Kelompok pasien non TB di rumah sakit memiliki kesempatan yang tinggi untuk mengakses informasi terkait TB dibandingkan kelompok pengungsi. Dengan akses informasi yang baik akan meningkatkan pemahaman baik tentang cara maupun manfaat pencegahan. Hal ini diperkuat adanya temuan bahwa salah satu yang berhubungan erat dengan perilaku pasien non TB di rumah sakit dalam melakukan pencegahan adalah akses informasi yang baik (Sokhanya et al., 2008).

Meskipun secara kumulatif lebih banyak responden yang masuk ke dalam kategori perilaku pencegahan penularan $\mathrm{TB}$ yang baik, untuk komponen penggunaan masker tercatat lebih banyak yang masuk ke dalam kategori buruk (59\%). Temuan ini perlu mendapat perhatian serius, karena saat batuk atau bersin, pasien TB dapat menyebarkan kuman ke udara dalam bentuk percikan dahak (droplet nuclei). Sekali batuk dapat menghasilkan sekitar 3000 percikan dahak (Kementerian Kesehatan RI, 2011). Penelitian juga menemukan tingginya resiko penularan akibat ketidakpatuhan penggunaan masker pada penderita TB (Martiana, Isfandiari, Sulistyowati, \& Nurmala, 2007). Di sisi lain, penelitian membuktikan bahwa masker menjadi salah satu cara yang efektif untuk pencegahan TB MDR (Dharmadhikari, Mphahlele, Stoltz, Venter, Mathebula, Masotla, et al., 2012).

Sebaliknya, dalam komponen pencegahan berupa etika batuk $(80,3 \%)$ dan pengobatan $(73,8 \%)$ merupakan komponen pencegahan dengan persentase kategori baik terbanyak. Hal ini berbeda dengan temuan penelitian yang menemukan justru pasien TB cenderung tidak baik dalam menjalankan etika batuk (Helper \& Sahat, 2010). Terkait perilaku pengobatan, pasien TB MDR dalam penelitian ini tetap menjalankan pengobatan dengan baik meski banyak di antara mereka mengeluhkan efek samping (pusing 83,6\% dan mual 90,1\%). Meski demikian, hasil ini perlu diwaspadai karena pengobatan TB MDR harus dijalankan dalam waktu yang lama dan munculnya efek samping pengobatan TB MDR pada dasarnya adalah hal yang wajar. Penelitian Munawwarrah dan Wahiduddin (2013) menemukan 100\% penderita TB MDR mengalami efek samping karena pengobatan. Efek samping yang tidak terkelola dengan dan berlangsung dalam jangka waktu lama tentunya dapat mempengaruhi/menurunkan perilaku individu dalam menjalani pengobatan. Penelitian sebelumnya juga membuktikan bahwa penghalang kepatuhan pengobatan pasien TB adalah munculnya efek samping obat (Bagiada, \& Primasari, 2010; Gebremariam, Bjune, \& Frich, 2010).

Baik buruknya perilaku pencegahan 
Iis Nurhayati: Perilaku Pencegahan Penularan dan Faktor-Faktor yang Melatarbelakanginya

dipengaruhi oleh banyak hal. Penelitian sebelumnya menemukan adanya hubungan yang bermakna antara perilaku pencegahan dengan pendidikan tinggi, usia lebih tua, status menikah (Thwin, 2008), agama Islam dan jenis kelamin wanita (Yusuf, 2014). Data sosiodemografi yang dikaji dalam penelitian ini (usia, jenis, kelamin, pendidikan, pernikahan, penghasilan, dan kategori pasien), terlihat hanya jenis kelamin yang menunjukkan bahwa pasien wanita memiliki perilaku pencegahan penularan TB-MDR yang lebih baik secara bermakna dibandingkan pasien pria $(\mathrm{p}=0,01)$.

Terkait faktor-faktor berdasarkan teori HBM, ditemukan adanya hubungan bermakna antara perceived benefit $(p<0,05)$, cues to action $(\mathrm{p}<0,01)$, dan self efficacy $(\mathrm{p}<0,05)$ dengan perilaku pencegahan penularan TB. Hal ini dapat dijelaskan, semakin positif persepsi pasien TBMDR tentang kemanfaatan (benefit), kecenderungan mengambil tindakan (cues to action) dan kepercayaan diri (self efficacy) dalam menjalankan penceghan penularan TB akan semakin baik perilaku pencegahanya dan sebaliknya (Glantz et al., 2008). Hasil ini didukung oleh temuan penelitian sebelumnya yang menemukan adanya hubungan yang bermakna antara perilaku dengan pengetahuan dan perceive benefit (Jahan, 2014).

Tabel 3, terlihat bahwa lebih dari setengah responden berersepsi positif terhadap susceptibility dan severity dan berpersepsi negatif terhadap barier. Hal ini bermakna lebih banyak pasien yang menganggap dirinya berisiko menimbulkan dampak negatif bila tidak melakukan pencegahan, serta tidak menemukan hambatan dalam menjalankan perncegahan. Meski demikian, analisis hubungan menunjukkan bahwa perceived susceptibilitiy \& severity dan barrier memiliki hubungan yang sangat rendah (tidak bermakna, $\mathrm{p}>0,05$ ) dengan perilaku pencegahan pasien TB MDR. Hal ini bermakna bahwa perilaku pencegahan pasien TB MDR dalam penelitian ini cenderung tidak terpengaruh, baik oleh persepsi mereka tentang kerentanan mereka untuk terkena/ menularkan ataupun hambatan mereka dalam melakukan pencegahan.

Temuan yang berbeda dilaporkan Jahan (2014), dimana terdapat hubungan positif yang bermakna antara perilaku pencegahan dengan persepsi kerentanan dan keparahan (susceptibility \& severity) serta hubungan negatif perilaku dengan perceive barrier (hambatan). Hal ini bermakna bahwa semakin tinggi persepsi pasien tentang kerentanan tertular dan keparahan bila tertular TB secara bermakna meningkatkan perilaku pencegahan. Sebaliknya, tingginya persepsi pasien terhadap hambatan/ kesulitan/kendala dalam menjalankan pencegahan semakin menurunkan perilaku pencegahan. Sejalan dengan hal tersebut, HBM menyatakan bahwa perilaku akan didukung oleh persepsi yang baik terkait benefit, kepercayaan diri, cues to action, dan kerentanan serta berhubungan terbalik dengan persepsi terkait hambatan (Glanz et al., 2008).

Temuan lebih lanjut menemukan adanya hubungan perceived benefit dengan cues to action dan self efficacy serta hubungan yang bermakna antara cues to action dan self efficacy. Hal ini bermakna bahwa semakin tinggi persepsi tentang kemanfaatan akan semakin tinggi kepercayaan diri dan semakin kuat kecenderungan untuk bertindak. Penelitian ini sejalan dengan penelitian Anias (2010) yang menemukan adanya hubungan bermakna antara self efficacy dengan perceived benefit terkait pengobatan TB. Self efficacy terbentuk dari penilaian diri terhadap kemampuan dan perasaan terhadap ancaman yang dapat menimbulkan motivasi untuk melakukan tindakan (Bandura, 2009).

Secara kategorik, lebih banyak responden dalam penelitian ini yang memiliki self efficacy yang buruk. Hasil ini bisa disebabkan karena pengalaman kegagalan pengobatan sebelumnya. Tercatat bahwa semua responden adalah TB MDR dengan riawayat kegagalan pengobatan (default, relaps, serta gagal pengobatan kategori 1 \& 2). Dalam proses pembentukan self-efficacy, pengalaman "negatif" masa lalu bisa menjadikan individu tidak yakin bisa menjalankan perilaku sejenis (pengobatan/pencegahan) di kemudian hari (Bandura, 2009). Hasil penelitian ini tidak sejalan dengan penelitian Hendiani, Sakti, dan Widianti (2012) yang menemukan bahwa rata-rata penderita TB memiliki efikasi diri yang tinggi. Meski demikian, penelitian ini dilakukan pada responden non TB MDR yang tentunya secara pengalaman/tantangan 
Iis Nurhayati: Perilaku Pencegahan Penularan dan Faktor-Faktor yang Melatarbelakanginya

pengobatan berbeda.

Menurut Anias (2006) cues to action bisa bersifat internal atau faktor eksternal yang mendukung kecendurungan pasien bertindak. Hal-hal yang terkait berupa pesan-pesan kesehatan melalui media masa, konsultasi dengan tenaga kesehatan atau anjuran teman yang mempengaruhi seseorang dalam memutuskan tindakannya. Hasil penelitian ini yang menunjukkan persepsi positif dan perilaku yang baik mengindikasikan faktor internal (motivasi dan pengetahuan) dan eksternal (layanan konsultasi, media informasi, dan pengelola program TB) yang baik. Di tempat penelitian (RSHS Bandung), pasien dengan TB MDR mendapatkan edukasi secara rutin, layanan konsultasi, serta reminder terkait jadwal kontrol. Dengan kondisi ini akan memfasilitasi pasien untuk mendapatkan akses informasi dan support yang baik dan mendorong mereka untuk lebih cenderung melakukan perilaku yang diharapkan.

\section{Simpulan}

Penelitian ini bertujuan mengidentifikasi perilaku pencegahan penularan TB MDR beserta faktor yang berhubungan dengan perilaku tersebut. Berdasarkan hasil penelitian dapat disimpulkan bahwa lebih dari setengah responden sudah memiliki perilaku pencegahan penularan TB MDR yang baik. Perilaku pencegahan penularan tersebut berhubungan secara bermakna dengan perceived benefit $(\mathrm{p}<0,05)$, cues to action $(\mathrm{p}<0,01)$, dan self efficacy $((\mathrm{p}<$ $0,05)$. Hal ini, guna meningkatkan perilaku pencegahan penularan pada pasien TB MDR, menjadi penting bagi perawat dan petugas kesehatan lainnya untuk memperkuat faktorfaktor tersebut. Salah satunya saat edukasi pasien TB MDR harus lebih menekankan pada kemanfaatan pencegahan penularan dan meyakinkan pasien bahwa mereka mampu menjalankan pencegahan penularan dengan baik.

\section{Daftar Pustaka}

Andriyanti, A.S. (2012). Faktor Risiko
Kejadian Tuberkulosis Resisten Obat Ganda (ROG). http://pustaka.unpad.ac.id/wpcontent.

Anias. (2006). Waspada Ancaman penyakit Tidak Menular, Solusi Pencegahan dari Aspek Perilaku dan Lingkungan. Jakarta: Elek Media Komputindo.

Bagiada, Primasari. (2010). Faktor yang Memengaruhi Tingkat Ketidakpatuhan Penderita Tuberculosis dalam Berobat di RSUP Sanglah Denpasar. Jurnal Penyakit Dalam, Vol 11.

Bandura, A. (2009). Cultivate Self-efficacy for Personal and Organizational Effectiveness., Handbook of Principles of Organization Behavior. Newyork: Wiley.

Bertin. (2011). Faktor-faktor Yang mempengaruhi Keberhasilan Pengobatan pada Pasien dengan Tuberkulosis Resistance di Jawa Tengah. Artikel Ilmiah Kedokteran .

Departemen Kesehatan. (2008). Pedoman pencegahan dan pengendalian Infeksi di Rumah Sakit dan Fasilitas Pelayanan Kesehatan Lainnya. Jakarta: Departemen Kesehatan.

Dharmadhikari, A.S., Mphahlele, M., Stoltz, A., Venter, K., Mathebula, R., Masotla, T., et al., (2012). Surgical Face Masks Worn by Patients with Multidrug-Resistant Tuberculosis. Ameican Journal Respiratory and Critical Care Medicine, 185, Iss. 10, pp 1104-1109, May 15, 2012.

Glanz, K. Rimer,B.K.Viswanath. (2008). Health Behavior and Health Education: Theory, Reseach, and Practice. San Francisco: Jossey Bass.

Helper \& Sahat, P.M. (2010). Faktor-faktor yang Mempengaruhi Kejadian TB Paru dan Upaya Penanggulangan. Jurnal Ekologi Kesehatan.

Hendiani, N., Sakti, H, Widayanti, C.G. (2010). The Relationship Between Family Support As Drug Consumption Controler / pengawas Minum Obat ( PMO)'s and Self 
Iis Nurhayati: Perilaku Pencegahan Penularan dan Faktor-Faktor yang Melatarbelakanginya

Efficacy of Tuberculosis Patient in BPKM Semarang Region. Jurnal Psikologi Undip, 1 .

Jahan, F (2014). Factors Related to Tuberculosis Preventive Behaviors among Tuberculosis Patients' Attendants in Dhaka, Bangladesh. Di akses http://digital collect. lib.buu.ac.th/dcms/files/55910280/title.pdf pada 2 Januari 2015.

Kementerian Kesehatan RI. (2011). Komunikasi,Informasi dan Edukasi Tuberculosis Resistance Obat. Jakarta: Sub Direktorat Tuberculosis. Programatic Management of Drugs Resistance Tuberculosis Indonesia. Jakarta. . (2014). Data dan Informasi Tahun 2013; Profil Kesehatan Indonesia. Jakarta.

Martiana, T. dkk. (2007). Analisis Resiko Penularan Tuberculosis Paru Akibat Faktor Perilaku dan Faktor Lingkungan Pada Tenaga kerja Industri. Berita Kedokteran Masyarakat, 23.

Munawwarah, R. Leida I, Wahiduddin. (2013). Gambaran Faktor Resiko pengobatan Pasien TB MDR RS Labuang Baji Kota Makasar. Jurnal Epidemiologi. Munir, S.M. (2010). Pengamatan Pasien Tuberkulosis Paru dengan Multi Drugs Resistant. Respirologi Indonesia.

Munir .S.M, Nawas. A, Soetoyo .D. (2010). Pengamatan Pasien Tuberculosis Paru dengan Multi Drug Resistant (TB MDR) di Poliklinik Paru RSUP Persahabatan. J Respir Indo ,30.

Register TB MDR RSUP DR. Hasan Sadikin Bandung, (2014). Buku Kunjungan TB MDR. Tidak dipublikasikan.
Sedjati, F. (2013). Hubungan Antara Efikasi Diri dan Dukungan Solial dengan Kebermaknaan Hidup pada penderita TB Paru di Balai Pengobatan Paru-paru (BP 4) Yogyakarta. Jurnal Psikologi.

Sihombing,H. Sembiring, H. Amir, Z. dan Sinaga, B.Y.M. (2012). Pola Resistensi Primer pada Penderita TB Paru Kategori I di RSUP H Adam Malik Medan. J Respir Indo, 3 .

Smeltzer, S.C., Bare, B.G., J.L., \& Cheever, K.H.(2010). Buku Ajar Keperawatan Medikal Bedah Brunner \& Suddarth's. Jakarta: EGC.

Sokhanya I, Sermsri, S \& Chompikul, J. (2008). TB Preventive Behavior of Patients Consulting at the General OutPatient Department at Paholpolpayuhasana Hospital, Kanchanaburi Province, Thailand di akses dari http://www.aihd.mahidol.ac.th/ sites/default/files/images/new/pdf/journal/ mayaug2008/6.pdf pada 2 Desember 2015.

Sukoco, N. E. (2011). Hubungan Antara Perilaku Pencegahan dan Kepatuhan Berobat Penderita TB di Indonesia. Buletin Penelitian Sistem Kesehatan, vol 14.

Thwin, HT. (2008). Preventive Behaviors of Tuberculosis among Myanmar Migrants in Muang Dstrict, Phuket Province - Thailand. Di akses dari http://cphs.healthrepository. org/bitstream/123456789/1443/1/Thesis Thawda2008.pdf pada 2 Desember 2015.

World Health Organization. (2013). Tuberculosis: WHO Global Tuberculosis Report. Fathsheet: World HealthOrganization.

Yusuf, FH (2014). Assessment of Prevention Behavioural Practices among Adult Tuberculosis Patients in Eastleigh Division, Nairobi County, Kenya. 